\title{
On the Usefulness of Search and Matching Models in Economics
}

\author{
Gaetano Lisi \\ Department of Economics, eCampus University, Novedrate, Italy \\ Email: gaetano.lisi@uniecampus.it
}

How to cite this paper: Lisi, G. (2021). On the Usefulness of Search and Matching Models in Economics. Theoretical Economics Letters, 11, 485-488.

https://doi.org/10.4236/tel.2021.113032

Received: April 26, 2021

Accepted: June 12, 2021

Published: June 15, 2021

Copyright $\odot 2021$ by author(s) and Scientific Research Publishing Inc. This work is licensed under the Creative Commons Attribution International License (CC BY 4.0).

http://creativecommons.org/licenses/by/4.0/

\begin{abstract}
Nowadays, the search and matching models are the primary and most popular theoretical tools used by economists to study all the "matching markets", not only the labour market. The benefit of using these models is discussed in this theoretical economics letter. Indeed, in addressing an important and recent economic issue, the standard and basic model in the style of Pissarides is used with no substantial changes.
\end{abstract}

\section{Keywords}

Matching Theory, Search Theory

\section{Introduction}

The search and matching models are the benchmark theoretical models of all "matching markets". The search and matching approach is, in fact, largely used also in the housing market (see, e.g., Genesove \& Lu, 2012; Cheng et al., 2015). Recently, moreover, the search and matching models have been used for studying the matching process between universities and innovative firms (see Calcagnini et al., 2016).

The central role of the search and matching models in economics was confirmed by The Sveriges Riksbank Prize in Economic Sciences in Memory of Alfred Nobel 2010 awarded to the founders of this approach: Peter Diamond, Dale Mortensen and Christopher Pissarides. Their Nobel lectures are a valuable starting point for deepening the search and matching theory (see Diamond, 2011; Mortensen, 2011; Pissarides, 2011).

Unlike the Walrasian markets, trade in the matching markets is a decentralised, uncoordinated and time-consuming economic activity. From a conceptual point of view, the benefit of using the search and matching models in economics 
is easy to understand. On the one hand, the search and matching models focus on aggregate probabilities of searching and matching, in that they are macroeconomic models; on the other hand, nothing is more microeconomic than "a match". Furthermore, a key feature of these models is the so-called matching function "that captures the implications of the costly trading process without the need to make the heterogeneities and other features that give rise to it explicit" (Pissarides, 2000: Chapter 1, p. 4). Concisely, heterogeneities and other key features, such as trading frictions and information imperfections, are implicitly included in the matching function and, thus, in the model.

The rest of this theoretical economics letter is organised as follows. In the next section the benefit of using these models is discussed. Precisely, we show that in addressing an important and recent economic issue, the standard and basic model in the style of Pissarides is used with no substantial changes. Final remarks are included in the last section.

\section{The Model}

In studying the matching process between universities and innovative firms, the standard labour market matching model in the style of Pissarides (Pissarides, 2000: Chapter 1) could be used without any adjustment. This is straightforward to show. Basically, the standard matching model is characterised by four key elements: 1) the ratio of vacancies to people searching; 2) the matching function; 3 ) the (intuitive) negative relationship between vacancies and people searching (the popular Beveridge Curve), and 4) the two equilibrium conditions: the Job Creation Condition and the Wage determination.

Firstly, the ratio of job vacancies to workers in search of a job, $\theta=v / s$, simply becomes the ratio of vacant projects $(v)$ to university researchers in search of a collaboration $(s)$. Also, the matching function $(m)$ can take the (usual) form of a Cobb-Douglas function with constant returns to scale, i.e. $m(v, s)=v^{\alpha} \cdot s^{1-\alpha}$, where $0<\alpha<1$ is the elasticity of the matching function with respect to vacant projects.

Hence, the unemployment dynamics in the standard and basic model in the style of Pissarides becomes the university researcher dynamics (in search of collaboration) in the matching model of university-industry collaborations, viz.:

$$
\dot{s} \equiv \frac{\mathrm{d} s}{\mathrm{~d} t}=\underbrace{\delta \cdot(N-s)}_{\text {inflow }}-\underbrace{\theta^{\alpha} \cdot s}_{\text {outflow }}
$$

where $\left(v^{\alpha} \cdot s^{1-\alpha}\right) / s=v^{\alpha} \cdot s^{-\alpha}=\theta^{\alpha}$ is the probability (with respect to people searching) of finding a job or a collaboration (of course, $\theta^{\alpha}$ is increasing in $\theta$ ); $N$ is the exogenous total number of workers (university researchers) and thus $(N-s)$ are the employed workers (university researchers) that lose their jobs (collaborations) at the exogenous "job destruction or separation" rate $\delta$. Therefore, in the steady-state (when $\dot{s}=0$ ), the famous Beveridge Curve simply becomes the Vacant Projects Curve, that is, the negative relationship between va- 
cant projects and university researchers in search of a collaboration, viz.:

$$
s=\frac{\delta \cdot N}{\theta^{\alpha}+\delta}
$$

with $\mathrm{d} s / \mathrm{d} v<0$.

As regards the labour demand side, the Job Creation Condition, which is obtained under the zero-profit or free-entry condition of a (one-job) firm, becomes the Collaboration Creation Condition, viz.:

$$
\frac{y-w}{r+\delta}=\frac{c}{\theta^{\alpha-1}}
$$

where $y$ is the real profit (in terms of output) of a firm, $w$ is the fee (instead of the wage), $r$ is the (constant) real interest rate, $c$ is the cost flow of a vacant project and the reciprocal of the probability of filling a vacancy $(\mathrm{m} / \mathrm{v})^{-1}$ denotes the average duration of a vacant project. In short, a firm opens a further vacancy until its value is reduced to zero. As usual, Equation (3) states that the (discounted) marginal benefit of a match (job or collaboration) equals the (discounted) marginal cost of the same match. The Creation Condition (CC) always depicts a negative relationship between $w$ and $\theta$. this is because a higher wage or fee implies a lower profit for firms, ceteris paribus.

Finally, the Wage determination, which is obtained under the common assumption of Nash bargaining, becomes the Fee determination, viz.:

$$
w=(1-\beta) \cdot b+\beta \cdot(y+c \cdot \theta)
$$

where $0<\beta<1$ is the bargaining power of workers (university researchers) and $b$ is the subsidy (the unemployment benefit in the labour market). In short, workers get a share $\beta$ of the total surplus of the match (if $\beta \rightarrow 0$, then $w \rightarrow b$ ). As usual, Equation (4) states that workers (university researchers) are rewarded for both the output and the saving of costs that a firm enjoys when a match is formed (note that the term $c \cdot \theta=c \cdot v / s$ represents the average cost of vacant projects). Of course, $w$ is increasing in $\theta$, since a higher $\theta$ indicates that the probability of finding a (new) job or a collaboration is higher (better outside options lead to more favourable bargains).

Concisely, Equations (1)-(4) describe the steady-state equilibrium of both the standard and basic model in the style of Pissarides and the matching model of university-industry collaborations. Precisely, Equations (3) and (4) jointly determine the steady-state equilibrium values of $w$ and $\theta$. Afterwards, given $\theta$, Equation (2) allows to determine the number of people searching for a job or a collaboration and, thus, the number of vacancies is obtained from the definition of $\theta=v / s$. Finally, $(N-s)$ gives the number of employed workers (university researchers).

\section{Final Remarks}

However, the standard model in the style of Pissarides (2000), precisely Chapter 1 (alone) is not able to consider several key features of the search and matching 
process between universities and innovative firms. Precisely, one needs to consider (at least):

- The endogenous job destruction (Pissarides, Chapter 2), because (realistically) not all the collaborations that are hit by a shock are destroyed;

- The key role of search intensity (Chapter 5). In fact, a greater search effort or intensity could work as a positive signal toward firms (a signal of a greater commitment, skills, efficiency and reliability of workers);

- The stochastic job matchings (Chapter 6), since the main question is not the matching but the outcome of the matching. In short, the meeting can also take place, but this does not imply that the matching is successful.

These features are especially important in highly specialised sectors, where innovative firms and university researchers operate.

\section{Acknowledgements}

The author wishes to thank the anonymous referee for the helpful remarks that have improved the paper.

\section{Conflicts of Interest}

The author declares no conflicts of interest regarding the publication of this paper.

\section{References}

Calcagnini, G., Giombini, G., Liberati, P., \& Travaglini, G. (2016). A Matching Model of University-Industry Collaborations. Small Business Economics, 46, 31-43. https://doi.org/10.1007/s11187-015-9672-y

Cheng, P., Lin, Z., Liu, Y., \& Seiler, M. J. (2015). The Benefit of Search in Housing Markets. Journal of Real Estate Research, 37, 597-622. https://doi.org/10.1080/10835547.2015.12091430

Diamond, P. (2011). Unemployment, Vacancies, Wages. American Economic Review, 101, 1045-1072. https://doi.org/10.1257/aer.101.4.1045

Genesove, D., \& Lu, H. (2012). Search and Matching in the Housing Market. Journal of Urban Economics, 72, 31-45. https://doi.org/10.1016/j.jue.2012.01.002

Mortensen, D. (2011). Markets with Search Friction and the DMP Model. American Economic Review, 101, 1073-1091. https://doi.org/10.1257/aer.101.4.1073

Pissarides, C. (2011). Equilibrium in the Labor Market with Search Frictions. American Economic Review, 101, 1092-1105. https://doi.org/10.1257/aer.101.4.1092

Pissarides, C. A. (2000). Equilibrium Unemployment Theory(2nd ed.). Cambridge, MA: MIT Press. 